\title{
Article \\ Kinetic Modeling and Mechanisms of Manganese Removal from Alkaline Mine Water Using a Pilot Scale Column Reactor
}

\author{
Shigeshi Fuchida ${ }^{1}$, Shota Tajima ${ }^{2}$, Takuro Nishimura ${ }^{3}$ and Chiharu Tokoro ${ }^{1,4, *(1)}$ \\ 1 Faculty of Science and Engineering, Waseda University, 3-4-1 Okubo, Shinjuku-ku, Tokyo 169-8555, Japan; \\ sfuchida@aoni.waseda.jp \\ 2 Graduate School of Creative Science and Engineering, Waseda University, 3-4-1 Okubo, \\ Shinjuku-ku, Tokyo 169-8555, Japan; shotaji-8279rib@fuji.waseda.jp \\ 3 Nagaoka International Corp., 1-8-15 Azuchimachi, Chuo-ku, Osaka 541-0052, Japan; \\ t-nishimura@nagaokajapan.co.jp \\ 4 Faculty of Engineering, The University of Tokyo, 7-3-1 Hongo, Bunkyo-ku, Tokyo 113-8656, Japan \\ * Correspondence: tokoro@waseda.jp; Tel.: +81-3-5286-3320
}

Citation: Fuchida, S.; Tajima, S.; Nishimura, T.; Tokoro, C. Kinetic Modeling and Mechanisms of Manganese Removal from Alkaline Mine Water Using a Pilot Scale Column Reactor. Minerals 2022, 12, 99. https://doi.org/10.3390/min12010099

Academic Editor: Carlito Tabelin

Received: 25 December 2021

Accepted: 13 January 2022

Published: 15 January 2022

Publisher's Note: MDPI stays neutral with regard to jurisdictional claims in published maps and institutional affiliations.

Copyright: (C) 2022 by the authors. Licensee MDPI, Basel, Switzerland. This article is an open access article distributed under the terms and conditions of the Creative Commons Attribution (CC BY) license (https:// creativecommons.org/licenses/by/ $4.0 /)$.

\begin{abstract}
Manganese (Mn) is a major element in various aqueous and soil environments that is sometimes highly concentrated in mine water and other mineral processing wastewater. In this study, we investigated $\mathrm{Mn}$ removal from alkaline mine water $(\mathrm{pH}>9)$ with an $\mathrm{Mn}$-coated silica sand packed into a pilot-scale column reactor and examined the specific reaction mechanism using X-ray absorption near-edge structure (XANES) analysis and geochemical kinetic modeling. The kinetic effect of dissolved $\mathrm{Mn}(\mathrm{II})$ removal by birnessite $\left(\delta-\mathrm{Mn}(\mathrm{IV}) \mathrm{O}_{2}\right)$ at $\mathrm{pH} 6$ and 8 was evaluated at different $\mathrm{Mn}(\mathrm{II}) / \mathrm{Mn}(\mathrm{IV})$ molar ratios of 0.1-10. Our results confirmed the positive effect of the presence of $\delta-\mathrm{MnO}_{2}$ on the short-term removal $(60 \mathrm{~min})$ of dissolved $\mathrm{Mn}$. XANES analysis results revealed that $\delta-\mathrm{MnO}_{2}$ was more abundant than $\mathrm{Mn}(\mathrm{III}) \mathrm{OOH}$ in the reactor, which may have accumulated during a long-term reaction (4 months) after the reactor was turned on. A gradual decrease in dissolved Mn(II) concentration with depth was observed in the reactor, and comparison with the kinetic modeling result confirmed that $\delta-\mathrm{MnO}_{2}$ interaction was the dominant $\mathrm{Mn}$ removal mechanism. Our results show that $\delta-\mathrm{MnO}_{2}$ contents could play a significant role in controlling $\mathrm{Mn}$ removability from mine water in the reactor.
\end{abstract}

Keywords: mine water; manganese oxidation; birnessite; pilot-scale column reactor

\section{Introduction}

Manganese $(\mathrm{Mn})$ is present as a major element in various aqueous and soil environments with different stable oxidation numbers (+ II, +III, +IV, +VI, and +VII); it shows similar bio-geochemical behavior to iron $(\mathrm{Fe})$ in the environment. Mining activities and mineral processing often produce Mn-rich water with concentrations of $100-1000 \mathrm{mg} \mathrm{L}^{-1}$ [1]. $\mathrm{Mn}$ is less toxic than other major trace metals (copper $(\mathrm{Cu})$, zinc $(\mathrm{Zn})$, and cadmium $(\mathrm{Cd})$ ) and metalloids (arsenic (As) and antimony $(\mathrm{Sb})$ ) but sometime shows similar toxicity to lead $(\mathrm{Pb})$ to most animals, including humans and various aquatic organisms; however, long-term exposure to high Mn-containing water is reported to cause chronic toxicity in the nervous and respiratory systems of living organisms [2,3]. Therefore, Mn removal from wastewater to a trace level is required to reduce the negative impacts on the aqueous environment and human health; the guidelines established by the World Health Organization limit the Mn concentration in drinking water to $0.4 \mathrm{mg} \mathrm{L}^{-1}$, which is 20-times lower than the effluent standard of Japan $\left(10 \mathrm{mg} \mathrm{L}^{-1}\right)[4,5]$.

Among metals generally contained in mine water, ferric ion (Fe(III)) and aluminum (Al) are precipitated at around $\mathrm{pH} 2-3$ and 3-5 to form hydroxide, respectively; as a result, trace metals such as $\mathrm{Pb}, \mathrm{Cu}, \mathrm{Zn}$, and $\mathrm{Cd}$ are effectively removed by surface complexation and/or coprecipitation with those hydroxides at $\mathrm{pH} 4-8$ when the mine water contains 
sufficient amounts of $\mathrm{Fe}(\mathrm{III})$ and $\mathrm{Al}$ rather than the removal of target metals [6-8]. On the other hand, $\mathrm{Mn}$ is difficult to remove by hydroxide formation without oxidation because its hydroxide $\left(\mathrm{Mn}(\mathrm{II})(\mathrm{OH})_{2}\right)$ is formed at $\mathrm{pH} 11$ and its abiotic oxidation rate by atmospheric air is very slow; e.g., half-life time is 3-7 days for $5 \mu \mathrm{M} \mathrm{Mn}$ (II) at $\mathrm{pH} 8.8$ [9]. For these reasons, various $\mathrm{Mn}$ removal processes from neutral-alkaline $\mathrm{pH}$ water is conducted without additional alkaline reagents like slake and quick limes.

Biological processes using Mn-oxidizing bacteria (MOB) have been suggested as an effective Mn removal process. The oxidation rate of $\mathrm{Mn}$ (II) by MOB is reported to be about five times higher than abiotic oxidation [10]. For Mn removal from mine water using a passive treatment technique, Fuchida et al. [11] found that Mn could be removed effectively from water at $\mathrm{pH}$ 6-8 using subsurface limestone beds (SLB) installed at the Motokura mine, in Hokkaido, Japan, and biological analysis using a next generation sequencer evidenced that the microorganism activity of the MOB in the SLB provided an opportunity for Mn (IV) dioxide $\left(\mathrm{MnO}_{2}\right)$ to form. The results from field observations and fundamental experiments indicate that MOB is appliable for the removal of Mn from mine water; however, $\mathrm{MOB}$ is generally heterotrophic but not autotrophic [12]. Thus, a continuous supplement of an energy source such as organic matter and the most suitable physicochemical conditions such as temperature and $\mathrm{pH}$ are issues when trying to maintain the removal performance of the reactor.

For Mn geochemical reactions, autocatalytic oxidation is recognized as an important reaction in the Mn oxidation process. Manganese dioxide can attract $\mathrm{Mn}$ (II) in solution and oxidize it on the surface as follows:

$$
\mathrm{Mn} \cdot \mathrm{MnO}_{2}+\mathrm{O}_{2 \mathrm{aq}} \rightarrow 2 \mathrm{MnO}_{2}
$$

The most general kinetic equation for Mn oxidation has been represented by Diem and Stumm [9] as follows:

$$
-d\left[\mathrm{Mn}^{2+}\right] / d \mathrm{t}=k_{1}\left[\mathrm{Mn}^{2+}\right]+k_{2}\left[\mathrm{Mn}^{2+}\right]\left[\mathrm{MnO}_{\mathrm{x}}\right]
$$

where $k_{1}$ and $k_{2}$ are rate constants where $k_{1}=k_{1^{\prime}}\left[\mathrm{O}_{2}\right]\left[\mathrm{OH}^{-}\right]^{2}, k_{1^{\prime}}=4 \times 10^{12} \mathrm{M}^{-3}$ day $^{-1}, k_{2}=$ $k_{2^{\prime}}\left[\mathrm{O}_{2}\right]\left[\mathrm{OH}^{-}\right]^{2}$, and $k_{2^{\prime}}=10^{18} \mathrm{M}^{-4}$ day $^{-1}$ _acquired from Diem and Stumm's experiments on abiotic systems [9]. A higher $k_{2^{\prime}}$ value than $k_{1^{\prime}}$ means that the amount of $\mathrm{MnO}_{\mathrm{x}}$ (autocatalysis) can greatly influence the $\mathrm{Mn}(\mathrm{II})$ oxidation rate. Recently, it has been suggested that the autocatalysis reaction be divided into several reaction steps as follows:

$$
\begin{aligned}
\equiv & \mathrm{MnOH}+\mathrm{Mn}^{2+} \rightarrow \equiv \mathrm{MnOMn}^{+}+\mathrm{H}^{+} \\
\equiv & \mathrm{MnOMn}^{+}+\mathrm{O}_{2 \mathrm{aq}}+\mathrm{H}_{2} \mathrm{O} \rightarrow 2 \mathrm{MnOOH} \\
& 2 \mathrm{MnOOH}+\mathrm{O}_{2 \mathrm{aq}} \rightarrow 2 \mathrm{MnO}_{2}+2 \mathrm{H}^{+}
\end{aligned}
$$

In the first step, divalent manganese ions $\left(\mathrm{Mn}^{2+}\right)$ form a complex on the $\mathrm{MnO}_{2}$ surface (Equation (3)) and is then oxidized to $\mathrm{Mn}(\mathrm{III}) \mathrm{OOH}$ by the disproportionation reaction (Equation (4)). Finally, $\mathrm{Mn}(\mathrm{III})$ is oxidized to $\mathrm{Mn}(\mathrm{IV})$ and incorporated to $\mathrm{MnO}_{2}$ (Equation (5)). Therefore, $\mathrm{Mn}$ removability by $\mathrm{MnO}_{2}$ can be controlled by the surface complexation capacity of $\mathrm{MnO}_{2}$. There are some polymorphic crystalline structures of $\mathrm{MnO}_{2}(\alpha, \beta$, and $\gamma$, etc.) with different physicochemical properties. Birnessite $\left(\delta-\mathrm{MnO}_{2}\right)$ is widely recognized as having a large surface area because of its layered crystalline structure: the specific surface area is over $700 \mathrm{~m}^{2} \mathrm{~g}^{-1}$, which is ten times higher than $\mathrm{MnOOH}$. The point of zero charge of $\delta-\mathrm{MnO}_{2}$ is $2-3$, meaning that various metals, including $\mathrm{Mn}$, are efficiently adsorbed under neutral-alkaline $\mathrm{pH}$ conditions; e.g., $\mathrm{Pb}$ [13], $\mathrm{Cd}$ [14], and $\mathrm{Zn}$ [15]. Many studies have extensively investigated the interaction between $\delta-\mathrm{MnO}_{2}$ and dissolved $\mathrm{Mn}^{2+}$; however, this reaction is a complex process and thus the comprehensive rate Equation (Equation (2)) is generally used to represent Mn removal behavior in natural systems. 
Various Mn removal techniques using precipitation, oxidation, adsorption, coagulation, and flotation processes are tested for treatment of high Mn-loading groundwater and wastewater which are generated by metallurgical engineering processes such as smelting and steelmaking [1]. However, the most major issue of these techniques is to use excess chemicals such as alkali (e.g., $\mathrm{Ca}(\mathrm{OH})_{2}$ and $\mathrm{CaCO}_{3}$ ), oxidizing (e.g., $\mathrm{HClO}_{4}$ ), and flocculation $\left(\mathrm{AlCl}_{3}\right)$ agents. Ion exchange using polymer resins is also used for $\mathrm{Mn}$ removal without addition of chemical agents, but the resins must be regenerated and also expensive, especially when treating a large amount of wastewater. Therefore, the development of efficient and inexpensive $\mathrm{Mn}$ removal techniques without chemicals is required to treat the wastewater and to decrease environmental loads. Furthermore, examples of Mn removal treatment process from mine water other than neutralization are less reported.

In this study, we investigated the removal process of $\mathrm{Mn}$ (II) from alkaline mine water by $\mathrm{Mn}$-coated sand packed into a pilot scale column reactor installed at $\mathrm{X}$ mine in Japan. Net alkaline mine water is generated by the reaction with carbonate minerals more than sulfide minerals; which sometime contains a high amount of Mn(II) and Zn [16]. The column reactor does not require additional chemicals for Mn removal from the alkaine mine water because Mn compounds is believed to work as an Mn scavenger. We constructed a geochemical model using the comprehensive rate equation based on the results of the batch removal experiment using synthesized $\delta-\mathrm{MnO}_{2}$ and the synchrotron analysis of column reactor samples in order to clear the Mn removal mechanisms and quantitatively evaluate the Mn removal capacity of this column reactor.

\section{Materials and Methods}

\section{1. $\mathrm{Mn}$ Removal Experiment with $\delta-\mathrm{MnO}_{2}$}

$\delta-\mathrm{MnO}_{2}$ was prepared according to our previous studies [14,15]; it was synthesized from $\mathrm{Mn}$ (II) solution by the addition of the oxidizing agent sodium hypochlorite $(\mathrm{NaClO})$ at $\mathrm{pH}$ 6. The $\mathrm{pH}$ value was measured by a $\mathrm{pH}$ meter (Horiba D-75, Horiba, Ltd., Kyoto, Japan) calibrated at $\mathrm{pH}$ values of 4.01, 7.00, and 10.01. The freeze dried $\delta-\mathrm{MnO}_{2}$ was mixed to $0.4 \mathrm{mmol} \mathrm{L}^{-1}\left(22 \mathrm{mg} \mathrm{L}^{-1}\right.$ ) Mn(II) solution at different $\mathrm{Mn}(\mathrm{IV}) / \mathrm{Mn}$ (II) molar ratios: $0.1,1$, and 10 , and then the suspension was stirred for $1 \mathrm{~h}$ after $\mathrm{pH}$ adjustment to 6 and 8 by addition of $1 \mathrm{~mol} \mathrm{~L}^{-1} \mathrm{KOH}$ solution. The reactant was acidified with $\mathrm{HNO}_{3}$ $(1 \%)$ in a polypropylene bottle after filtration with $0.45 \mu \mathrm{m}$ polytetrafluoroethylene (PTFE) membrane filter (ADVANTEC Japan Co. Ltd., Tokyo, Japan) and stored until analysis.

\subsection{Pilot Scale Mn Removal Test}

$\mathrm{X}$ mine is located in Aomori prefecture in Japan and the pilot-scale column reactor for Mn removal from the mine water is shown in Figure 1. $X$ mine is a hydrothermal vein deposit containing sphalerite, pyrite and rhodochrosite [17]. The volume of the cylinder column reactor was $0.28 \mathrm{~m}^{3}$ (the length and cross-sectional area were $4 \mathrm{~m}$ and $0.07 \mathrm{~m}^{2}$, respectively). Gravel (size $\varphi 2-12 \mathrm{~mm}$ ) was placed in the bottom $0.5 \mathrm{~m}$ of the reactor, followed by silica sand (size $\varphi 0.6 \mathrm{~mm}$ ) that occupied a space of $2.5 \mathrm{~m}$ above the gravel. The average inflow rate was $5.0( \pm 0.3) \mathrm{L} \mathrm{min}^{-1}$ and the flux was $0.82 \mathrm{~cm} \mathrm{~s}^{-1}$. The inflow rate to the column reactor was controlled with a controller pump which connected from the drainage tank to the reactor. The reactor was on from 11 June to 30 October 2020, and the samples used in this study were collected on 8 October 2020. The chemical composition of the water put in to the column reactor prior to the sample collection is listed in Table 1. The $\mathrm{pH}$ value was around 9.6, meaning that most metal ions (Fe(III), $\mathrm{Al}$, and $\mathrm{Zn}$ ) were not dissolved in the water (below detection limit of our measurement). Among the metals, $\mathrm{Mn}$ had the highest concentration at over $5.8 \mathrm{mg} \mathrm{L}^{-1}$ and sulfate had the highest concentration among the anions $\left(820 \mathrm{mg} \mathrm{L}^{-1}\right)$ in the water. The solution samples were collected from sampling ports set at $0.3,0.7,1.05,1.45,1.85,2.1,2.45$, and 2.9 (outflow) $\mathrm{m}$ depth from the top of the column. The $\mathrm{pH}$ and dissolved oxygen $(\mathrm{DO})$ values of the solution were measured by a $\mathrm{pH} / \mathrm{DO}$ meter (Horiba D-75, Horiba, Ltd., Kyoto, Japan). The sample was stored with $\mathrm{HNO}_{3}(1 \%)$ in a polypropylene bottle after filtration with a $0.45 \mu \mathrm{m}$ polytetrafluoroethylene 
(PTFE) membrane filter. Mn-coating silica sand samples were also collected from the upper (0.3 $\mathrm{m}$ depth), middle (1.25 $\mathrm{m}$ depth), and lower (2.25 $\mathrm{m}$ depth) parts of the reactor and stored at $-20^{\circ} \mathrm{C}$. The solid sample was dried in a vacuum before solid analysis.

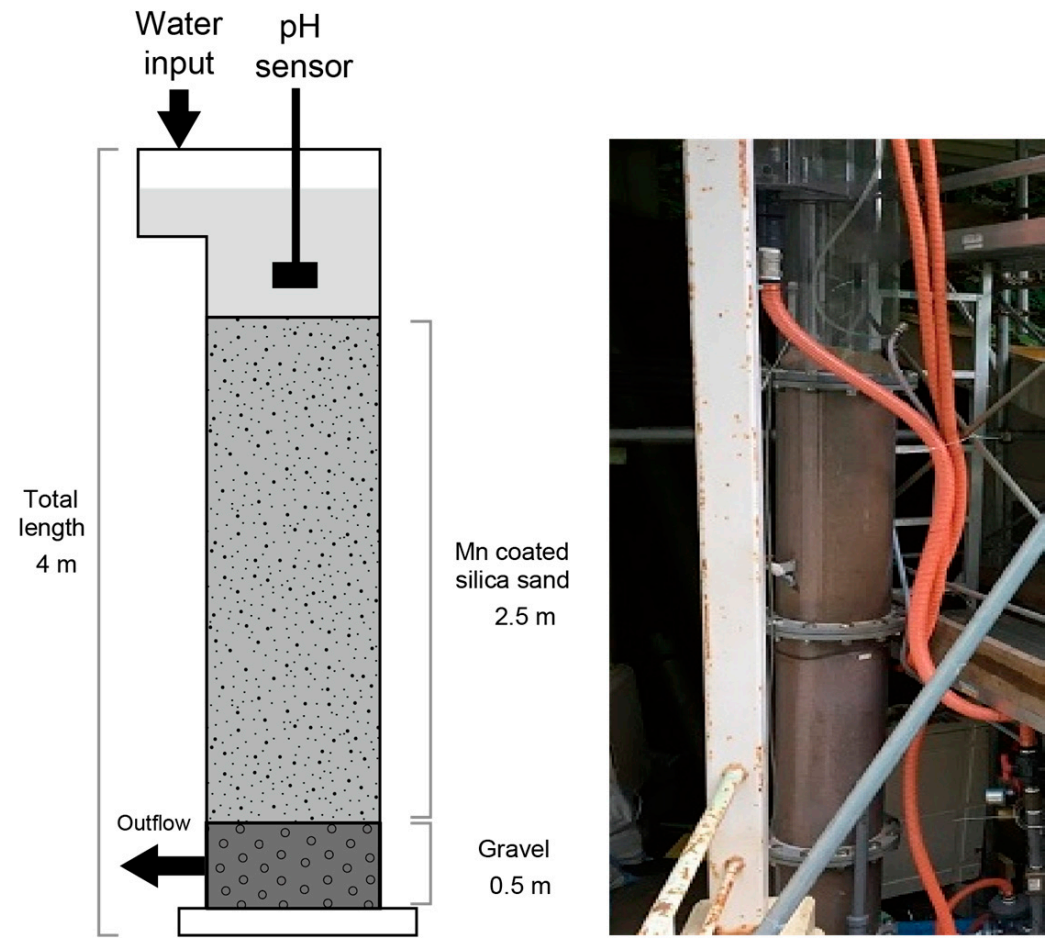

Figure 1. A schematic image and picture of the pilot-scale column reactor for $\mathrm{Mn}$ removal installed at $\mathrm{X}$ mine (Aomori, Japan).

Table 1. The chemical composition of water input into the column reactor.

\begin{tabular}{rrrrrrrrrr}
\hline \multicolumn{10}{c}{ Concentrations $\left(\mathbf{m g ~ L}^{-1}\right)$} \\
\hline $\mathbf{N a}^{+}$ & $\mathbf{K}^{+}$ & $\mathbf{C a}^{+}$ & $\mathbf{M n}^{2+}$ & $\mathbf{A l}^{3+}$ & $\mathbf{Z n}^{2+}$ & $\mathbf{C d}^{2+}$ & $\mathbf{S O}_{4}{ }^{2-}$ & $\mathbf{C l}^{-}$ \\
\hline 89 & 1.6 & 11 & 5.8 & 0.051 & 0.078 & 0.0021 & 820 & 29 \\
\hline
\end{tabular}

To evaluate the amount of Mn coating on the silica sand, the dried sample (1.0 g) was reacted with $0.5 \mathrm{M}$ hydroxylammonium chloride solution $(40 \mathrm{~mL})$ for $16 \mathrm{~h} \mathrm{[18]}$ and the reacted solution was preserved in a polypropylene bottle after filtration with a $0.45 \mu \mathrm{m}$ PTFE filter.

\subsection{Analysis}

2.3.1. Quantification of Chemical Components in Water Samples

Manganese concentrations in the solution samples were determined by inductively coupled plasma-mass spectrometry (ICP-MS; 8800 ICP-QQQ, Agilent Technologies, Inc., Santa Clara, CA, USA). The detection limit of Mn was $0.01 \mu \mathrm{g} \mathrm{L}^{-1}(\mathrm{RSD}<5 \%)$ in this analysis. All chemicals used in this study were analytical grade and purchased from Wako Pure Chemical Industries, Ltd. (Osaka, Japan).

\subsubsection{XANES Analysis of Mn in Solid Samples}

The Mn K-edge X-ray absorption fine structure (XAFS) analysis Mn oxides on silica sand particulates was measured using the BL5S1 beamline at Aichi Synchrotron Radiation Center, Japan. The dried sample was diluted with boron nitride and formed into pellets of $10 \mathrm{~mm}$ diameter and $1.0 \mathrm{~mm}$ thickness. The X-ray absorption near-edge structure (XANES) region of the energy range 6540-6590 eV was measured by the transmission 
method using silica (111) monochromator crystals. Various manganese oxides $\left(\delta-\mathrm{MnO}_{2}\right.$, $\mathrm{Mn}(\mathrm{II}) \mathrm{O}$ (manganosite), $\mathrm{Mn}(\mathrm{II}, \mathrm{III})_{3} \mathrm{O}_{4}$ (hausmannite), $\gamma-\mathrm{Mn}(\mathrm{III}) \mathrm{OOH}$ (manganite), and $\mathrm{Mn}(\mathrm{III})_{2} \mathrm{O}_{3}$ ) were used as reference materials. The contents of each Mn compound in the solid samples were quantified with the linear combination fitting (LCF) of XANES spectra using the Athena software package. Additionally, the valence of those Mn compounds in the solid samples were quantified by the K-edge white peak position of XANES spectra. Many previous studies have reported that there is a good liner relationship between the Mn K-edge position and Mn valence $[19,20]$. The white peak position of XANES spectra was found using the Athena software package.

\subsection{Geochemical Modeling by PHREEQC}

Geochemical code PHREEQC ver.3 (USGS) was used to simulate the behavior of $\mathrm{Mn}$ removal from the water path through the test column by coupling various chemical reactions and one-dimensional advection analysis [21]. The specific chemical species and equilibrium constants were published in a previous study [11,14,15,22]. Similar rate equations for Mn oxidation to Equation (2) were used in our geochemical modeling, but the reaction order and the amount of $\mathrm{MnO}_{2}$ was determined by fitting to the experimental result of the $\mathrm{Mn}$ removal experiment with $\delta-\mathrm{MnO}_{2}$ (Section 2.1). Output data and measured values were summarized and schematic diagrams were produced using Microsoft Excel, and diagrams were drawn using Adobe Illustrator.

\section{Results and Discussion}

\subsection{Kinetic Modeling of $\mathrm{Mn}$ Removal by $\delta-\mathrm{MnO}_{2}$}

Figure 2 shows the temporal changes in the dissolved $\mathrm{Mn}^{2+}$ concentration in the solutions that reacted with $\delta-\mathrm{MnO}_{2}$ at different $\mathrm{Mn}(\mathrm{IV}) / \mathrm{Mn}(\mathrm{II})$ molar ratios: $0.1,1$, and 10 . At both $\mathrm{pH}$ conditions, dissolved $\mathrm{Mn}^{2+}$ concentrations decreased gradually as the reaction proceeded; it was completely removed within the first $30 \mathrm{~min}$ after the start of the reaction at the highest $\mathrm{Mn}(\mathrm{IV}) / \mathrm{Mn}(\mathrm{II})$ molar ratio. The $\mathrm{Mn}$ removal rate increased with increasing $\mathrm{Mn}(\mathrm{IV}) / \mathrm{Mn}(\mathrm{II})$ molar ratio conditions, indicating that $\delta-\mathrm{MnO}_{2}$ may play the role of both an oxidizing agent and/or an adsorbent of $\mathrm{Mn}^{2+}$ in this reaction system.

(a)

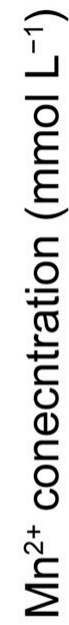

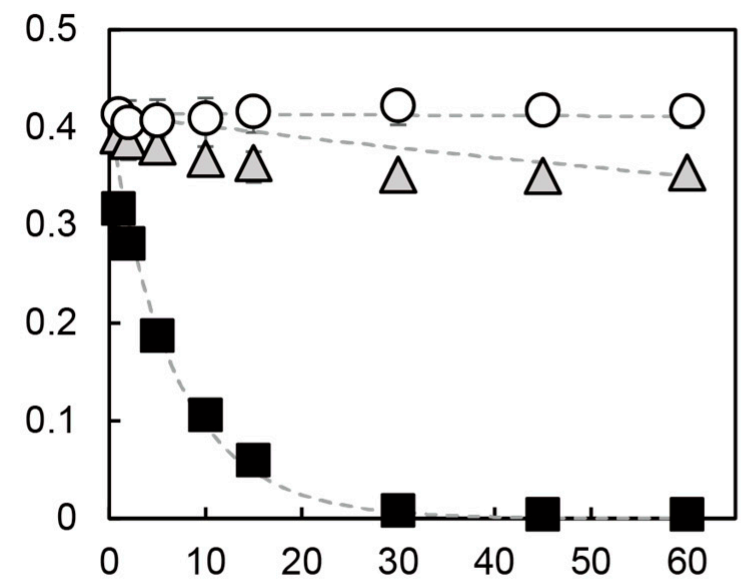

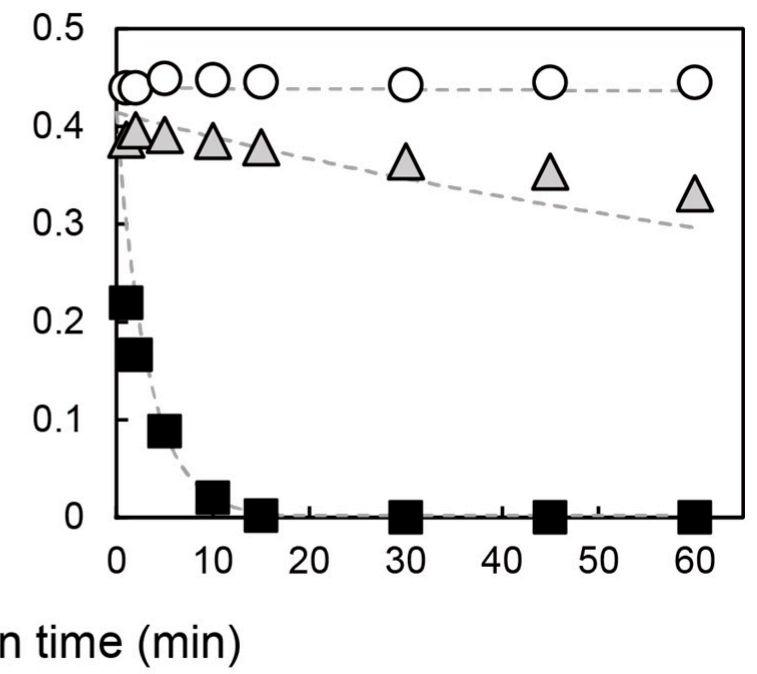

\section{$\mathrm{Mn}(\mathrm{IV}) / \mathrm{Mn}(\mathrm{II})$ molar ratios: $0.1 \bigcirc 1 \triangle 10 \square \quad$ Calculated value:--.--}

Figure 2. Dissolved $\mathrm{Mn}^{2+}$ removal behavior in the presence of $\delta-\mathrm{MnO}_{2}$ at (a) $\mathrm{pH} 6$ and (b) $\mathrm{pH} 8$ and calculation results by PHREEQC. Plots show mean values of duplicates. 
Fitting the results to the experimental values gave 1.9 as the reaction order for the amount of $\delta-\mathrm{MnO}_{2}$ in the $\mathrm{Mn}$ oxidation rate equation; thus, the following removal rate equation was used for this study:

$$
-d\left[\mathrm{Mn}^{2+}\right] / d \mathrm{t}=k_{1}\left[\mathrm{Mn}^{2+}\right]+k_{2}\left[\mathrm{Mn}^{2+}\right]\left[\mathrm{MnO}_{2}\right]^{1.9}
$$

Similar rate constants $\left(k_{1}\right.$ and $\left.k_{2}\right)$ to Diem and Stumm's experiment [9] were used in this calculation. Although the reaction order for the amount of $\delta-\mathrm{MnO}_{2}$ represents a combination influence of oxidation and surface complexation by $\delta-\mathrm{MnO}_{2}$ in our study, several researchers have quantitatively evaluated the specific Mn adsorption behavior of the $\delta-\mathrm{MnO}_{2}$ surface. Tonkin et al. [23] investigated the order of affinity of various metals for hydrous $\mathrm{Mn}$ oxides (HMO), which was believed to be a poorly crystalline $\delta-\mathrm{MnO}_{2}$ via two site surface complexation modeling, and revealed that $\mathrm{Mn}$ showed the highest affinity for $\mathrm{HMO}$ among the studied divalent metals (cobalt $\left(\mathrm{Co}^{2+}\right), \mathrm{Cu}^{2+}, \mathrm{Zn}^{2+}$, nickel $\left(\mathrm{Ni}^{2+}\right)$, and $\left.\mathrm{Cd}^{2+}\right)$. Spectroscopic analysis has revealed that there are two adsorption sites, i.e., triple-corner-sharing (TCS) and double-corner sharing (DCS) sites, on the $\delta$ - $\mathrm{MnO}_{2}$ surface [24], and the TCS (interlayer vacancy) site mainly works to uptake metal ions from the solution into the interlayer of $\delta-\mathrm{MnO}_{2}$. A recent study [13] evaluated the adsorption mechanisms and order of affinity for various metals on the TCS site of $\delta$ - $\mathrm{MnO}_{2}$ using a charge distribution multiple site complexation (CD-MUSIC) model. This thermodynamic calculation showed that the adsorption affinities of metals had the following order at the TCS site: $\mathrm{Pb}^{2+}>\mathrm{Cu}^{2+}>\mathrm{Co}^{2+}>\mathrm{Cd}^{2+}>\mathrm{Mn}^{2+}>\mathrm{Zn}^{2+}>\mathrm{Ni}^{2+}$. These results indicate that the selectivity of $\mathrm{Mn}$ adsorption could easily change depending on the solution chemistry and surface properties of $\delta-\mathrm{MnO}_{2}$. Once $\mathrm{Mn}^{2+}$ is adsorbed onto the $\delta-\mathrm{MnO}_{2}$ surface, it is oxidized to $\beta$ - $\mathrm{MnOOH}$ (feitknechtite) by a disproportionation reaction and then changed to $\gamma-\mathrm{MnOOH}$ and/or $\mathrm{Mn}_{3} \mathrm{O}_{4}$ because $\beta$-MnOOH is thermodynamically unstable under normal atmospheric conditions [25]. The interaction between $\mathrm{Mn}^{2+}$ and the $\delta-\mathrm{MnO}_{2}$ surface shows a significantly complex redox process compared to $\mathrm{Fe}(\mathrm{II})$; thus, we used the comprehensive rate Equation (Equation (6)) to represent Mn removal behavior in the pilot scale column reactor.

\subsection{Mn Removal Mechanism and Capacity in Column Reactor}

Figure 3 shows (a) the XANES spectra of Mn-coated samples collected from the reactor and reference materials and (b) the liner fitting result of the reference materials for the $\mathrm{Mn}$ valance estimation. Three major $\mathrm{Mn}$ compounds $\left(\mathrm{Mn}_{3} \mathrm{O}_{4}, \gamma-\mathrm{MnOOH}\right.$, and $\left.\delta-\mathrm{MnO}_{2}\right)$ could be formed as a thermodynamically stable phase under normal temperature water conditions as explained below; thus, the content of these Mn compounds in each sample was determined by the LCF result. The XANES analysis results for Mn-coated sands shows similar Mn valance (3.5-3.7) regardless of sampling depth; however, the amounts of $\mathrm{Mn}_{3} \mathrm{O}_{4}$, $\gamma-\mathrm{MnOOH}$, and $\delta-\mathrm{MnO}_{2}$ were different between the upper and lower parts of the column reactor (Table 2). $\delta-\mathrm{MnO}_{2}$ was the dominant $\mathrm{Mn}$ compound at all sampling depths, whereas a lower amount of $\gamma-\mathrm{MnOOH}$ was found at the upper and middle depths.

Table 2. Mn valence value and molar percentage of each Mn compound determined by XANES analysis using Athena.

\begin{tabular}{ccccc}
\hline & \multirow{2}{*}{ Mn Valence } & \multicolumn{3}{c}{ Ratio (mol \%) } \\
\cline { 3 - 5 } & & $\mathbf{M n}_{\mathbf{3}} \mathbf{O}_{\mathbf{4}}$ & $\boldsymbol{\gamma}$-MnOOH & $\delta$ - $\mathbf{M n O}_{\mathbf{2}}$ \\
\hline Upper & 3.7 & 25 & 0.70 & 74 \\
\hline Middle & 3.5 & 38 & 0.0 & 62 \\
\hline Under & 3.6 & 21 & 17 & 62 \\
\hline
\end{tabular}


(a)

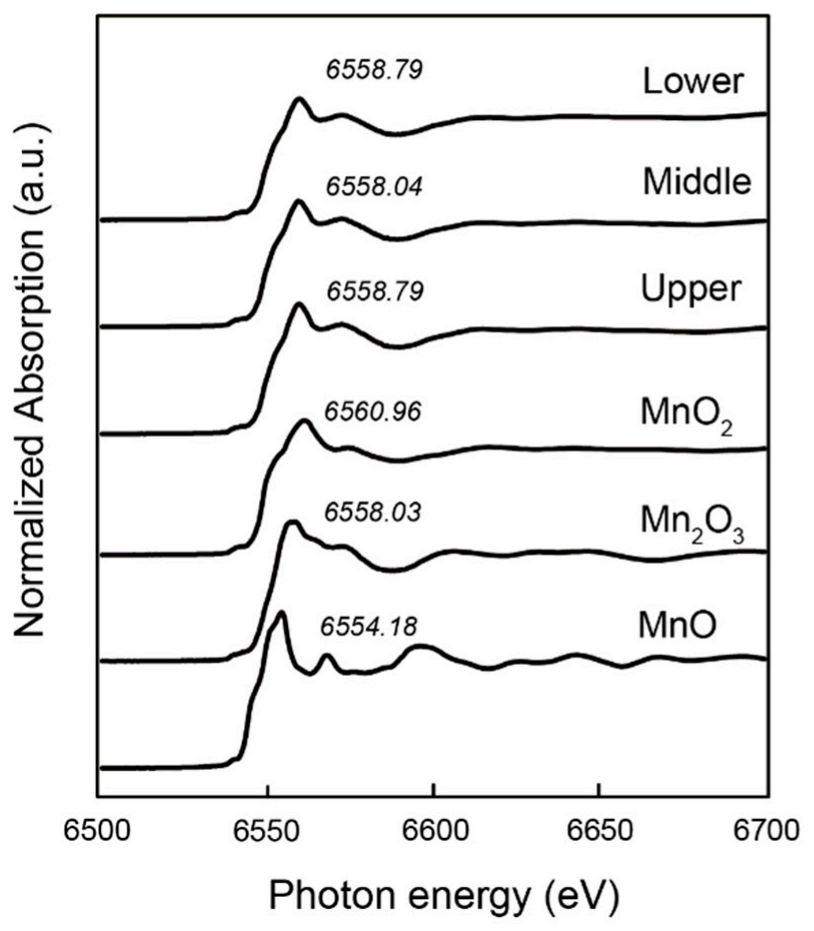

(b)

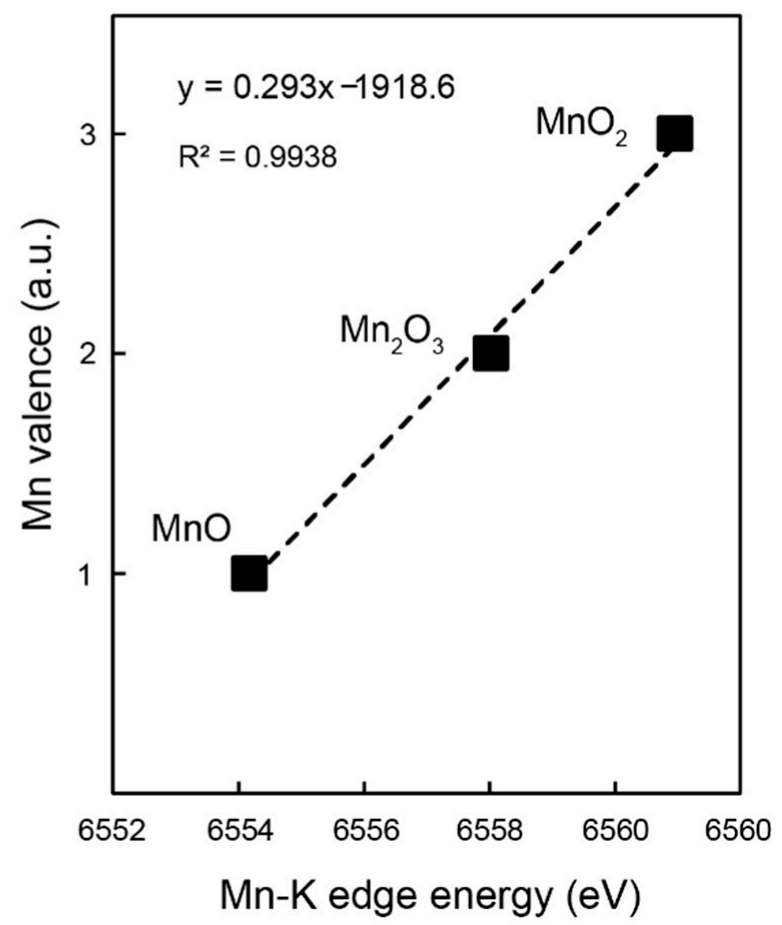

Figure 3. (a) Mn-edge XANES spectra of Mn-coated sands sampled from column reactor and reference material and (b) the linear relationship between the Mn K-edge position and Mn valence. The values shown on each XANES peak represents the white line position determined by Athena.

$\mathrm{Mn}_{3} \mathrm{O}_{4}$ is generally precipitated as the first Mn oxidation compound, which consists of both divalent and trivalent $\mathrm{Mn}$ as follows [13]:

$$
6 \mathrm{Mn}^{2+}+\mathrm{O}_{2 \mathrm{aq}}+6 \mathrm{H}_{2} \mathrm{O} \rightarrow 2 \mathrm{Mn}_{3} \mathrm{O}_{4}+12 \mathrm{H}^{+}
$$

$\mathrm{MnOOH}$ is formed as the result of the oxidation of aqueous $\mathrm{Mn}^{2+}$ and $\mathrm{Mn}_{3} \mathrm{O}_{4}$ as follows:

$$
\begin{gathered}
4 \mathrm{Mn}^{2+}+\mathrm{O}_{2 \mathrm{aq}}+6 \mathrm{H}_{2} \mathrm{O} \rightarrow 4 \mathrm{MnOOH}+8 \mathrm{H}^{+} \\
\mathrm{Mn}_{3} \mathrm{O}_{4}+2 \mathrm{H}_{2} \mathrm{O} \rightarrow 3 \mathrm{MnOOH}+\mathrm{H}^{+}
\end{gathered}
$$

These reactions release hydrogen ions, promoting $\mathrm{MnOOH}$ formation at alkaline $\mathrm{pH}$ conditions rather than acidic $\mathrm{pH}$ conditions. Disproportionation reactions also form $\mathrm{MnOOH}$ and $\mathrm{MnO}_{2}$ as follows [26]:

$$
\begin{gathered}
\mathrm{Mn}_{3} \mathrm{O}_{4}+2 \mathrm{H}^{+} \rightarrow 2 \mathrm{MnOOH}+\mathrm{Mn}^{2+} \\
2 \mathrm{MnOOH}+2 \mathrm{H}+\rightarrow \mathrm{MnO}_{2}+\mathrm{Mn}^{2+}+2 \mathrm{H}_{2} \mathrm{O}
\end{gathered}
$$

These disproportionation reactions are estimated to become thermodynamically unfavorable under alkaline $\mathrm{pH}$ conditions because they consume hydrogen ions. In addition, the disproportionation reaction of $\mathrm{MnOOH}$ is a dehydration reaction. Based on this thermodynamic theory, therefore, $\mathrm{MnO}_{2}$ formation could be promoted by autocatalytic reactions (Equation (5)) and direct oxidation under alkaline $\mathrm{pH}$ conditions rather than the disproportionation reactions of $\mathrm{MnOOH}$, which is consistent with the results of our $\mathrm{Mn}^{2+}$ removal experiment using synthesized $\delta-\mathrm{MnO}_{2}$ (Figure 2).

The extraction method using hydroxylammonium chloride solution revealed that the amount of Mn coating on silica sand was 1.1, 0.95 , and $0.86 \mathrm{~mol} \mathrm{~kg}^{-1}$ dried sample collected from the upper, middle, and lower parts of the column reactor, respectively. The mole 
percentage of each Mn compound was calculated from this. The XANES results are shown in Table 3. This result also confirmed that most of the Mn was in the form of $\delta-\mathrm{MnO}_{2}$. As mentioned above, samples were collected after the reactor column had been active for 4 months, meaning that $\delta-\mathrm{MnO}_{2}$ was accumulated on silica sand particles.

Table 3. The amount of each Mn compound was calculated from the extraction experiment and XANES analysis results.

\begin{tabular}{cccc}
\hline & \multicolumn{3}{c}{ Amount $\left(\mathbf{m o l ~ m}^{-\mathbf{1}}\right)$} \\
\cline { 2 - 4 } & $\mathbf{M n}_{\mathbf{3}} \mathbf{O}_{\mathbf{4}}$ & $\boldsymbol{\gamma}$-MnOOH & $\boldsymbol{\delta}$-MnO $\mathbf{~}_{\mathbf{2}}$ \\
\hline Upper & 68.6 & 1.90 & 203 \\
\hline Middle & 77.3 & 0.00 & 127 \\
\hline Under & 48.6 & 39.2 & 142 \\
\hline Average & 64.9 & 13.7 & 157 \\
\hline
\end{tabular}

Figure 4 shows the changes in the dissolved Mn(II) concentration with column reactor depth of Mn-coated sand layer measured values and calculated values using our geochemical model. The DO value of mine water slightly decreased from 9.0 to 7.5 during the path through the Mn-coated silica sand layer, but enough DO for Mn oxidation could be presented in the column reactor. The amount of $\delta-\mathrm{MnO}_{2}$ related to $\mathrm{Mn}$ removal was estimated by fitting to the measured values because only part of the total $\delta-\mathrm{MnO}_{2}$ could be activated and play a role in reacting with dissolved $\mathrm{Mn}^{2+}$ in the column reactor [23]. The amount of activated $\delta-\mathrm{MnO}_{2}$ was calculated as $0.03 \mathrm{~mol} \mathrm{~m}^{-1}$, which is only $0.02 \%$ of the total $\delta-\mathrm{MnO}_{2}$ in the column reactor. Only the surface $\delta-\mathrm{MnO}_{2}$ of the $\mathrm{Mn}$-compound layer on the silica particles could be reactive and contribute to removing $\mathrm{Mn}^{2+}$ from the alkaline mine water. The solution $\mathrm{pH}$ increased from 9.6 to 8.6-8.7 from the top to the bottom of the reactor, which is explained by the direct oxidation of $\mathrm{Mn}^{2+}$ to $\mathrm{Mn}_{3} \mathrm{O}_{4}$ and/or $\mathrm{MnOOH}$ and an autocatalytic reaction with $\delta-\mathrm{MnO}_{2}$ because these reactions release hydrogen ions as explained above. Our geochemical modeling revealed that the interaction with $\delta-\mathrm{MnO}_{2}$ was the main removal mechanism of $\mathrm{Mn}^{2+}$.

For Mn removal from mine water, various $\mathrm{Mn}$ removal techniques have been examined; e.g., precipitation with carbonate $\mathrm{Mn}(\mathrm{II}) \mathrm{CO}_{3}$ and sulfide $\mathrm{Mn}(\mathrm{II}) \mathrm{S}$, adsorption by ion exchange membrane, and coagulation/flocculation with additional reagents such as $\mathrm{AlCl}_{3}$ as explained in the introduction part [1]. Among these removal techniques, oxidation and filtration could be widely used for metal mine water treatment because of the simple reaction system [1]. Many researchers have studied Mn removal from mine water with varying $\mathrm{pH}$ values using limestone column reactors. Silver et al. [27] conducted a continuous Mn removal experiment using different size limestone and found that initial $\mathrm{pH}$ conditions greatly influenced $\mathrm{Mn}$ removability: it became lower at acidic $\mathrm{pH}$ conditions $(\mathrm{pH}<4)$ because the adsorption of $\mathrm{Mn}^{2+}$ on the calcite surface and carbonate formation were inhibited at the acidic $\mathrm{pH}$ condition. Le Bourre et al. [28] used limestone and halfcalcinated dolomite $\left(\mathrm{CaMg}\left(\mathrm{CO}_{3}\right)_{2}\right)$ to remove $\mathrm{Mn}$ from three different natural and simulated mine water samples (different $\mathrm{pH}(2.4-6.8)$ and Mn concentrations (0.6-47 $\left.\mathrm{mg} \mathrm{L}^{-1}\right)$ ). They found that $\mathrm{Mn}$ was immobilized by $\mathrm{MnO}_{\mathrm{x}}$, which could be formed under long-term (for 255 days) contact of Mn solution with limestone and dolomite. These carbonate minerals could contribute to increase $\mathrm{pH}$ as a neutralizer and supply a carbonate ion to form $\mathrm{MnCO}_{3}$. However, general mine water contains high amounts of $\mathrm{SO}_{4}{ }^{2-}$ (over several hundred or thousand $\mathrm{mg} \mathrm{L}^{-1}$ ), which is derived from the oxidative dissolution of sulfide minerals [29]. Calcium sulfate is formed around limestone particles by a reaction with sulfate-rich water, resulting in a decrease in metal removability due to passivation [30]. Furthermore, high ferrous ion (Fe(II)) concentration also inhibits Mn removal from mine water by carbonate minerals because Fe(II) can reduce $\mathrm{Mn}$ (III) and $\mathrm{Mn}(\mathrm{IV})$ to $\mathrm{Mn}$ (II) by the deprotonation reaction and decrease the active mineral surface area by passivation and the formation of 
hydroxide $\left(\mathrm{Fe}(\mathrm{OH})_{3}\right)[28,30]$. Postma and Appelo [31] investigated the kinetic effect of the co-presence of $\mathrm{Fe}$ (II) on $\mathrm{Mn}$ removal by natural $\delta-\mathrm{MnO}_{2}$-coated sand that was collected from lake sediment in Ikast, Denmark, and reported that $\delta-\mathrm{MnO}_{2}$ decomposition is a first order rate reaction dependent on the Fe activity, resulting in $\mathrm{MnOOH}$ formation. As explained above, $\delta-\mathrm{MnO}_{2}$ shows a higher reactivity than $\mathrm{MnOOH}$ because of a higher surface area (about ten times higher than $\mathrm{MnOOH}$ ). A reduction in $\delta-\mathrm{MnO}_{2}$ is thought to be a serious problem to maintaining the removal performance of $\mathrm{Mn}$ and other metal cations by Mn-coated sand. Our result clearly shows that Mn was effectively removed from the mine water even though it contains a significant amount of $\mathrm{SO}_{4}{ }^{2-}\left(820 \mathrm{mg} \mathrm{L}^{-1}\right)$ when $\mathrm{Fe}(\mathrm{II})$ concentration was low; therefore, pretreatment to remove $\mathrm{Fe}^{2+}$ and long-term oxidation to accumulate $\delta-\mathrm{MnO}_{2}$ could enhance the removability of $\mathrm{Mn}$ and other metals using a Mn-coated sand column reactor. This technique would be suitable for sustainable mine water treatment rather than limestone treatment such as SLB and contribute efficient and inexpensive Mn removal from mine water.

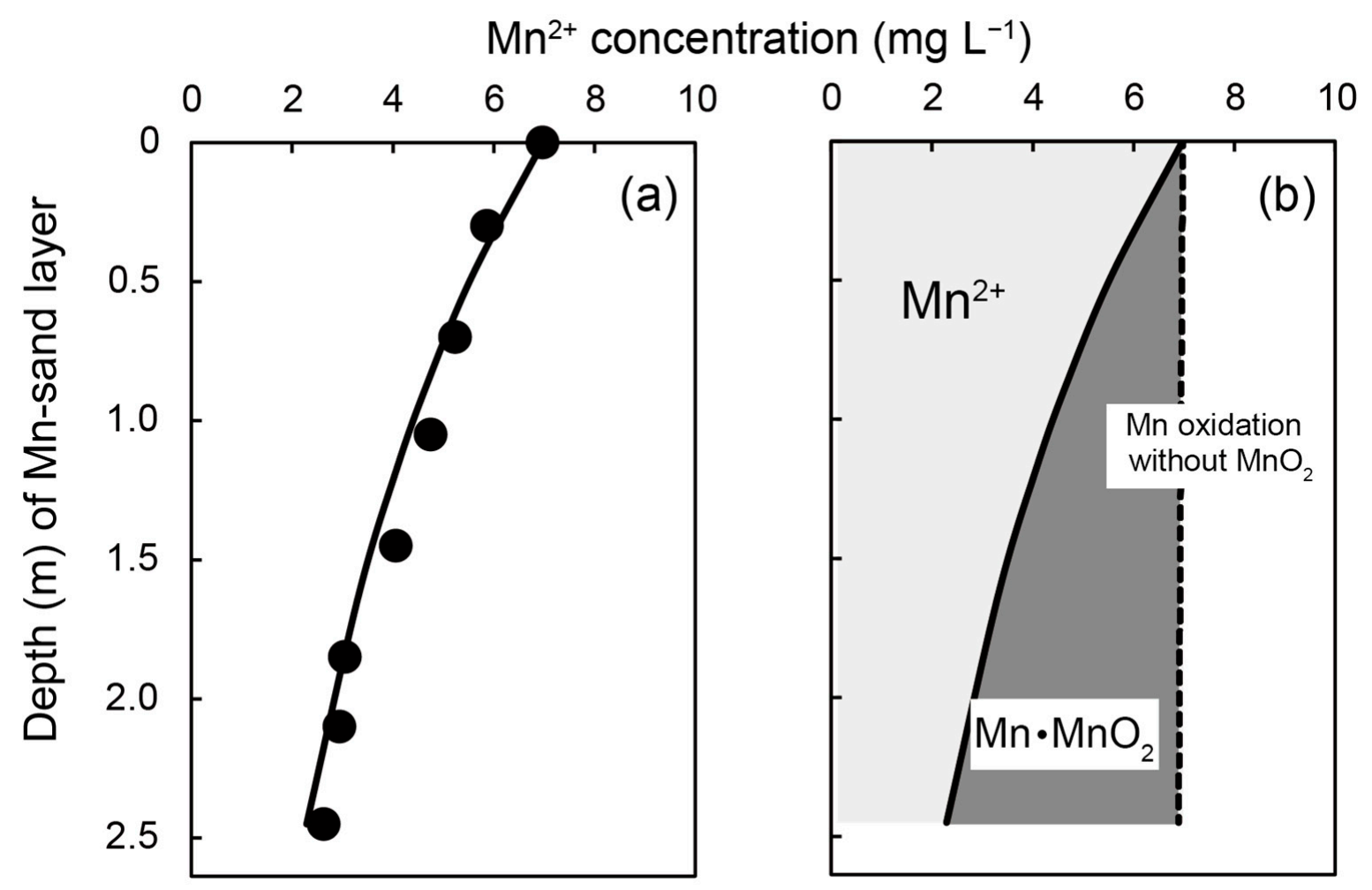

Figure 4. Mn removal behavior in the pilot scale column: changes in dissolved (a) Mn concentration and (b) its removal reaction with the depth of the column reactor and the comparison between measured (plots) and calculated (lines) results by PHREEQC.

Our result shows the interaction with $\delta-\mathrm{MnO}_{2}$ was the main removal mechanism of $\mathrm{Mn}^{2+}$ rather than simple oxidation and precipitation reactions, and $\mathrm{Mn}$ removal behavior could be represented by the comprehensive rate equation which has been demonstrated by Diem and Stumm [9], indicating this kinetic model is useful to examine Mn removal mechanism in actual wastewater treatment systems. However, $\mathrm{Mn}$ interaction with $\mathrm{MnO}_{2}$ is a significantly complex process, i.e., surface complexation and disproportionation reaction. In addition, there are many polymorphic minerals of $\mathrm{MnO}_{2}$. Thus, a kinetic model including all specific reactions for $\mathrm{Mn}-\mathrm{MnO}_{2}$ interactions could be required to estimate more accurately and quantitatively $\mathrm{Mn}$ removal capacity in actual wastewater treatment systems. 


\section{Conclusions}

In this study, we investigated $\mathrm{Mn}$ removability from alkaline mine water $(\mathrm{pH}>9)$ with Mn-coated silica sand packed into a column reactor and examined the specific reaction mechanism. A gradual decrease in dissolved Mn(II) concentration with column reactor depth was observed and a comparison with the results of kinetic modeling confirmed that the interaction with $\delta-\mathrm{MnO}_{2}$ was the main removal mechanism of $\mathrm{Mn}^{2+}$. Therefore, the $\mathrm{Mn}$ removability could be controlled by the amount of activated $\delta-\mathrm{MnO}_{2}$ presence in the reactor rather than total $\mathrm{Mn}$ mineral contents. Although our study targeted the alkaline mine water with a simple chemical composition (less Fe and other heavy metals), most mine water shows acidic $\mathrm{pH}$ and contains high amounts of $\mathrm{Fe}^{2+}$, which inhibits efficient $\mathrm{Mn}$ removal. Recently, the interaction between $\delta-\mathrm{MnO}_{2}$ and dissolved metals, including $\mathrm{Fe}^{2+}$ and $\mathrm{Mn}^{2+}$, has been extensively investigated; however, the quantitative evaluation of the specific reaction is inadequate to evaluate the actual efficiency of this technique for mine water treatment. Therefore, more thermodynamic and kinetic data about the nature of $\mathrm{Mn}$ minerals are required to estimate applicable mine water composition and suitable treatment conditions for this technique.

Author Contributions: Conceptualization, S.F. and C.T.; methodology, S.F. and S.T.; sample preparation and experiment, T.N.; analysis and calculation, S.T.; validation, S.F. and S.T.; writing-original draft preparation, S.F.; writing-review and editing, S.F., C.T. and S.T.; funding acquisition, C.T. All authors have read and agreed to the published version of the manuscript.

Funding: This research was partially funded by Nagaoka International Corp. (2019FY-2021FY) and JOGMEC (Japan Oil, Gas and Metals National Corporation) (2019FY-2021FY).

Data Availability Statement: Not applicable.

Acknowledgments: Part of this work was performed at the Waseda Research Institute for Science and Research Organization for Open Innovation Strategy, Waseda University. The synchrotron radiation experiments were performed using a BL5S1 beamline courtesy of the Aichi Synchrotron Radiation Center, Aichi Science \& Technology Foundation, Aichi, Japan.

Conflicts of Interest: The authors declare no conflict of interest.

\section{References}

1. Patil, S.D.; Chavan, M.S.; Kennedy Oubagaranadin, U.J. A review of technologies for manganese removal from wastewaters. J. Environ. Chem. Eng. 2016, 4, 468-487. [CrossRef]

2. Avila, S.D.; Gubert, P.; Roos, H.D.; Puntel, R.; Aschner, M. Manganese. Ency. Food Health 2016, 441, 637-640.

3. Carlito, B.T.; Park, I.; Phengsaart, T.; Jeon, S.; Villacorte-Tabelin, M.; Alonzo, D.; Yoo, K.; Ito, M.; Hiroyoshi, N. Copper and critical metals production from porphyry ores and E-wastes: A review of resource availability, processing/recycling challenges, socio-environmental aspects, and sustainability issues. Resour. Conserv. Recycl. 2021, 170, 105610.

4. WHO (World Health Organization). Manganese in Drinking-water. In Background Document for Development of WHO Guidelines for Drinking Water Quality; WHO: Geneva, Switzerland, 2011.

5. MOE (Ministry of the Environment, Government of Japan). Uniform National Effluent Standards. Available online: https: //www.env.go.jp/water/impure/haisui.html (accessed on 8 December 2021).

6. Scheinost, C.A.; Abend, S.; Pandya, I.K.; Sparks, L.D. Kinetic controls on Cu and Pb sorption by ferrihydrite. Environ. Sci. Technol. 2001, 35, 1090-1096. [CrossRef] [PubMed]

7. Tokoro, C.; Yatsugi, Y.; Koga, H.; Owada, S. Sorption mechanisms of arsenate during coprecipitation with ferrihydrite in aqueous solution. Environ. Sci. Technol. 2010, 44, 638-643. [CrossRef] [PubMed]

8. Tokoro, C.; Sakakibara, T.; Suzuki, S. Mechanism investigation and surface complexation modeling of zinc sorption on aluminum hydroxide in adsorption/coprecipitation processes. Chem. Eng. J. 2015, 279, 86-92. [CrossRef]

9. Diem, D.; Stumm, W. Is dissolved $\mathrm{Mn}^{2+}$ being oxidized by $\mathrm{O}_{2}$ in absence of Mn-bacteria or surface catalysts? Geochim. Cosmochim. Acta 1984, 48, 1571-1573. [CrossRef]

10. Piazza, A.; Casalini, C.L.; Pacini, A.V.; Sanguinetti, G.; Ottado, J.; Gottign, N. Environmental bacteria involved in manganese(II) oxidation and removal from groundwater. Front. Microbiol. 2019, 10, 119. [CrossRef]

11. Dick, G.J.; Podell, S.; Johnson, H.A.; Rivera-Espinoza, Y.; Bernier-Latmani, R.; McCarthy, J.K.; Torpey, J.W.; Clement, B.G.; Gaasterland, T.; Tebo, B.M. Genomic insights into Mn(II) oxidation by the marine alphaproteobacterium Aurantimonas sp.Strain SI85-9A1. Appl. Environ. Microbiol. 2008, 74, 2646-2658. [CrossRef] 
12. Fuchida, S.; Suzuki, K.; Kato, T.; Kadokura, M.; Tokoro, C. Understanding the biogeochemical mechanisms of metal removal from acid mine water with a subsurface limestone bed at the Motokura Mine, Japan. Sci. Rep. 2020, 10, 20889231. [CrossRef]

13. Li, Y.; Zhao, X.; Wu, J.; Gu, X. Surface complexation modeling of divalent metal cation adsorption on birnessite. Chem Geol. 2019, 551, 119774. [CrossRef]

14. Suzuki, K.; Kato, T.; Fuchida, S.; Tokoro, C. Removal mechanisms of cadmium by $\delta-\mathrm{MnO}_{2}$ in adsorption and coprecipitation processes at pH 6. Chem. Geol. 2020, 550, 119744. [CrossRef]

15. Tajima, S.; Fuchida, S.; Tokoro, C. Coprecipitation mechanisms of Zn by birnessite formation and its mineralogy under neutral $\mathrm{pH}$ conditions. J. Environ. Sci. 2021, in press.

16. Kelly, J.; Champagne, P.; Michel, F. Mitigation of alkaline mine drainage in a natural wetland system. WIT Trans. Ecol. Environ. 2006, 89, 115-124.

17. Yamamoto, G.; Nagamine, T.; Kitagaki, T.; Unno, T. Discovery of the manganese nodule in groundwater from the Oppu Mine, Aomori Prefecture, Japan. Earth Sci. 2004, 58, 375-388, (In Japanese with English Abstract).

18. Suda, A.; Makino, T.; Higashi, T. Extractability of manganese and iron oxides in typical Japanese soils by $0.5 \mathrm{~mol} \mathrm{~L}-1 \mathrm{hydroxy}-$ lamine hydrochloride (pH 1.5). Soil Sci. Plant Nutr. 2012, 58, 684-695. [CrossRef]

19. Ressler, T.; Wong, J.; Roos, J.; Smith, L.J. Quantitative Speciation of Mn-Bearing Particulates Emitted from Autos Burning (Methylcyclopentadienyl)manganese Tricarbonyl-Added Gasolines Using XANES Spectroscopy. Environ. Sci. Technol. 2000, 34, 950-958. [CrossRef]

20. Jiao, F.; Frei, H. Nanostructured manganese oxide clusters supported on mesoporous silica as efficient oxygen-evolving catalysts. Chem. Commun. 2010, 46, 2920-2922. [CrossRef]

21. Parkhurst, D.L.; Appelo, C.A.J. Description of Input and Examples for PHREEQC Version 3-A Computer Program for Speciation, Batch-Reaction, One-Dimensional Transport, and Inverse Geochemical Calculations; U.S. Geological Survey: Reston, VA, USA, 2013.

22. Kato, T.; Yagisawa, M.; Matsuoka, M.; Tokoro, C.; Sakakibara, T.; Hayashi, K. Quantitative modeling incorporating surface complexation for the treatment of acid mine water. Kagaku Kogaku Ronbunshu 2017, 43, 207-212, (In Japanese with English abstract). [CrossRef]

23. Tonkin, W.J.; Laurie SBalistrieri, S.L.; Murray, W.J. Modeling sorption of divalent metal cations on hydrous manganese oxide using the diffuse double layer model. Appl. Geochem. 2004, 19, 29-53. [CrossRef]

24. Van Genuchten, C.M.; Peña, J. Sorption selectivity of birnessite particle edges: A d-PDF analysis of $\mathrm{Cd}(\mathrm{ii})$ and $\mathrm{Pb}(\mathrm{ii}) \mathrm{sorption}$ by $\delta-\mathrm{MnO}_{2}$ and ferrihydrite. Environ. Sci. Processes Impacts 2016, 18, 1030-1041. [CrossRef] [PubMed]

25. Lefkowitz, P.J.; Rouff, A.A.; Elzinga, J.E. Influence of $\mathrm{pH}$ on the Reductive Transformation of Birnessite by Aqueous Mn(II). Environ. Sci. Technol 2013, 47, 10364-10371. [CrossRef] [PubMed]

26. Hem, D.J.; Roberson, E.C.; Fournier, B.R. Stability of $\beta \mathrm{MnOOH}$ and manganese oxide deposition from springwater. Water Resour. Res. 1982, 18, 563-570. [CrossRef]

27. Silva, A.M.; Cruz, L.S.F.; Lima, M.F.R.; Teixeira, C.M.; Leão, A.V. Manganese and limestone interactions during mine water treatment. J. Hazard. Mater. 2010, 181, 514-520. [CrossRef] [PubMed]

28. Le Bourre, B.; Carmen, M.; Neculita, M.C.; Coudert, L.; Rosa, E. Manganese removal processes and geochemical behavior in residues from passive treatment of mine water. Chemosphere 2020, 259, 127424. [CrossRef] [PubMed]

29. Santomartino, S.; Webb, J.A. Estimating the longevity of limestone drains in treating acid mine water containing high concentrations of iron. Appl. Geochem. 2007, 22, 2344-2361. [CrossRef]

30. Soler, J.M.; Boi, M.; Mogollón, J.L.; Cama JAyora, C.; Nico, S.P.; Tamura, N.; Kunz, M. The passivation of calcite by acid mine water Column experiments with ferric sulfate and ferric chloride solutions at pH 2. Appl. Geochem. 2008, 23, 3579-3588. [CrossRef]

31. Postma, D.; Appelo, A.C. Reduction of Mn-oxides by ferrous iron in a flow system: Column experiment and reactive transport modeling. Geochim. Cosmochim. Acta 2000, 64, 1237-1247. [CrossRef] 